\title{
Nitrogen cycling rates and light effects in tropical Lake Maracaibo, Venezuela
}

\author{
Wayne S. Gardner and Joann F. Cavaletto
}

NOAA Great Lakes Environmental Research Laboratory, 2205 Commonwealth Blvd., Ann Arbor, Michigan 48105

\author{
Harvey A. Bootsma ${ }^{2}$ and Peter J. Lavrentyev ${ }^{1,3}$ \\ Cooperative Institute for Limnology and Ecosystems Research, University of Michigan, 2200 Bonisteel Blvd., Ann Arbor, \\ Michigan 48109
}

\section{Federico Troncone}

Instituto para el Control y la Conservacion de la Cuenca del Lago Maracaibo (ICLAM), Maracaibo, Estado Zulia, Venezuela

\begin{abstract}
Isotope dilution experiments with ${ }^{15} \mathrm{NH}_{4}^{+}$were conducted in Lake Maracaibo, Venezuela, to examine potential $\mathrm{N}$ turnover rates and light effects and to examine the hypothesis that nutrient dynamics are biologically driven in this tropical, hypereutrophic lake. Ammonium and nitrate concentrations were both $<1 \mu \mathrm{M}$ as compared to particulate $\mathrm{N}$ concentrations of 9-29 $\mu \mathrm{M} \mathrm{N}$. Chlorophyll (Chl) levels ranged from 2.5 to $22 \mu \mathrm{g} \mathrm{liter}{ }^{-1}$. Numbers and biomass of bacteria ranged from 1.0 to $9.1 \times 10^{6}$ cells $\mathrm{ml}^{-1}$ and 45 to $138 \mu \mathrm{g} \mathrm{C}$ liter ${ }^{-1}$ and those of heterotrophic nanofla-

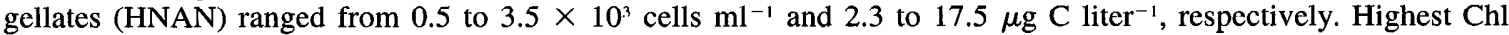
concentration and microbial abundance occurred in a region affected by sewage discharge from the city of Maracaibo. Potential ammonium uptake rates in near-surface waters ranged from about $1 \mu \mathrm{M} \mathrm{h}^{-1}$ to $8 \mu \mathrm{M} \mathrm{h} \mathrm{h}^{-1}$. Chlspecific uptake rates were highest in central regions that were dominated by chroococcoid cyanobacteria. Ammonium regeneration rates ranged from near detection to $2 \mu \mathrm{M} \mathrm{h}^{-1}$ and correlated significantly with the ratio of HNAN to bacterial biomass, likely reflecting the degree of bacterivory. The high ratio of potential turnover rates to ambient ammonium concentrations suggests that internal recycling is a major nutrient supply process in the lake. Incubation bottle characteristics (e.g., light intensity, spectral quality, or possibly headspace differences) apparently affected potential uptake rates, which were relatively low in polystyrene bottles and in quartz tubes. Uptake rates were lower in screened polystyrene bottles than in screened polypropylene syringes, with different spectral characteristics, even though total light attenuation was similar (45\% vs. $53 \%)$.
\end{abstract}

Internal cycling of nutrients is an important factor contributing to plankton productivity, but it has not been extensively studied in tropical lakes (Kilham and Kilham 1990; Lewis 1987) except for some studies in Lake Calado, Brazil (Fisher et al. 1988; Morrissey and Fisher 1988). Some features of tropical lakes resemble those of temperate lakes in summer (Kalff and Watson 1986), but contrasts are greater

\footnotetext{
1 Present address: University of Texas Marine Science Institute, 750 Channelview Drive, Port Aransas, Texas 78373.

${ }^{2}$ Present address: SADC/GEF Lake Malawi/Nyasa Biodiversity Conservation Project, P.O. Box 311, Salima, Malawi.

${ }^{3}$ Present address: University of Akron, Department of Biology, Akron, Ohio 44325-3908.

\section{Acknowledgments}

This research was supported as a joint effort by The Instituto para el Control y la Conservacion de la Cuenca del Lago Maracaibo (ICLAM) and the NOAA Great Lakes Environmental Research Laboratory. The Nancy Lee and Perry Bass Chair Endowment to the University of Texas Marine Science Institutc helped support manuscript preparation. We thank ICLAM scientists and staff and the crew of the R/V Bergantin for their technical help during the cruise, G. Lavrentyeva for sharing unpublished phytoplankton data, R. Benner for helpful suggestions, and J. Cotner and T. Johengen for reviewing the manuscript. The Venezuelan Airforce provided information on meteorological conditions in the region of Lake Maracaibo. This paper is GLERL contribution 1040.
}

during other parts of the year. Information on nutrient cycling from temperate lakes cannot necessarily be extrapolated to tropical lakes, because of the fundamental differences in the physical and biological dynamics of the two types of systems. For example, temperature-driven spring (and autumn) water column turnover in large temperate lakes delivers oxygen to hypolimnetic regions and reloads the euphotic zone with nutrients that in turn set the stage for seasonal ecological and nutrient cycling patterns throughout the season (Scavia and Fahnenstiel 1987). In contrast, tropical lakes often do not have strong seasonal water column mixing patterns and can develop more permanently anoxic hypolimnia. If nutrient substrates are available, water column nutrients may recycle more rapidly in tropical lakes than in temperate ones because higher temperatures tend to enhance biological activity and enzyme reactions (Chróst and Overbeck 1987; Lewis 1987). Based on nutrient ratios and theoretical considcrations, elemental cycles in tropical lakes were hypothesized to be dominated by biological control, whereas those in temperate lakes are dominated by physical processes during much of the year (Kilham and Kilham 1990). On the other hand, photochemical reactions that can affect primary production (Hader 1996; Vincent and Roy 1993) and associated processes (Lindell et al. 1996) in near-surface waters should be pronounced in tropical and subtropical lakes where light insolation is often higher than in temperate systems (Kirk 1994; Lewis 1987). 
Tropical hypereutrophic lakes, such as Lake Maracaibo, Venezuela, should provide favorable conditions for high nutrient cycling rates and photochemical effects. Surveys of Lake Maracaibo over the last $40 \mathrm{yr}$ have provided some information about primary production rates and about the standing stocks of major foodweb organisms, nutrients, dissolved oxygen, salinity, and other water-quality characteristics (Gessner 1956 cited by Parri-Pardi 1983; Redfield 1958; Redfield and Earlston Doe 1964; Sutton 1974; Parri-Pardi 1986). Primary productivity is very high in the lake with values as high as 3-8 $\mathrm{g} \mathrm{C} \mathrm{m}^{-2} \mathrm{~d}^{-1}$ reported for the northeastern area of the lake (Sutton 1974). However, little information is available about internal nutrient cycling rates and the factors that control them in the lake. Lake Maracaibo is a desirable site to study the effects of light on $\mathrm{N}$ cycling rates because of its solar-intense location and because $\mathrm{N}$ is considered to be the nutrient most limiting to phytoplankton in the lake (based on N:P ratios; Parri-Pardi 1986). We hypothesized that pelagic ammonium regeneration, by microbial food wcb organisms, is a major $\mathrm{N}$ supply mechanism to plankton and that near-surface cycling rates are affected by sunlight in this nutrient-rich tropical lake.

Our objectives were to measure potential $\mathrm{N}$ turnover rates, as defined by ammonium dynamics, and to examine the effects of microbial food web composition and different light conditions on potential uptake and regeneration rates of ammonium in surface and subsurface waters in Lake Maracaibo. Specific questions are: (1) What are potential uptake rates and regeneration rates for ammonium and how do they vary spatially? (2) How do these rates relate to the structure and abundance of the microbial food web? (3) What is the effect of light intensity/quality on uptake and regeneration rates? (4) Does photochemical oxidation of dissolved organic N (DON) by sunlight contribute measurably to ammonium regeneration in Lake Maracaibo surface waters?

\section{Lake Maracaibo characteristics}

Located between $9^{\circ} 00^{\prime} \mathrm{N}$ and $10^{\circ} 30^{\prime} \mathrm{N}$ latitude, Lake Maracaibo is a tropical lake and remains warm $\left(\sim 28-32.5^{\circ} \mathrm{C}\right.$; mean $30^{\circ} \mathrm{C}$ ) throughout the annual seasonal cycle. Lake Maracaibo is about $150 \mathrm{~km}$ long and $110 \mathrm{~km}$ wide and is the largest lake in South Amcrica. It has a mean depth of $25 \mathrm{~m}$ and a maximum depth of $34 \mathrm{~m}$ (Parri-Pardi 1983). This estuarine lake is connected to the Gulf of Venezuela via the Strait of Maracaibo and Bay El Tablazo and is brackish due to intrusion of salty waters from the strait to the hypolimnion in the center of the lake. The cone-shaped hypolimnion is defined by higher salinity and lower temperature than the overlying epilimnetic water that circulates around the hypolimnion in a counterclockwise direction (Parri-Pardi 1986). Wind directions, described for different regions of the lake by Parra-Pardi (1983) are considered to be a major cause for this vortex current pattern. Wind-driven tides occasionally can create a seiche effect severe enough to rupture cone stability and allow nutrient-rich hypolimnetic waters to mix into the epilimnion. The climate of the Lake Maracaibo basin ranges from being dry in the north $\left(40 \mathrm{~cm}\right.$ rainfall $\left.\mathrm{yr}^{-1}\right)$ to humid in the south $\left(260 \mathrm{~cm}\right.$ rainfall $\mathrm{yr}^{-1}$; Parra-Pardi
$1983)$. Although near-cloudless days $(<12.5 \%$ coverage $)$ occur on some days (e.g., $9 \mathrm{~d}$ in 1995 and $26 \mathrm{~d}$ in 1996 in the northern region), skies over Lake Maracaibo usually have intermediate cloud coverage. High cloud coverage (more than 87.5\%) occurred in Maracaibo on $54 \mathrm{~d}$ in 1995 and on $30 \mathrm{~d}$ in 1996 (data provided by Venezuelan Airforce). On an annual basis, days with measurable precipitation occur only about $14 \%$ of the time in the northern region where data are available. However, the amount of rainfall varies seasonally. For example, in the city of Maracaibo, measurable precipitation occurs $0-2 \mathrm{~d}^{\text {month }}{ }^{-1}$ during the months of December through April, as compared to 4-9 d month ${ }^{-1}$ during May through November (http://www.infoasis.com/ people/stevetwt/Weather/weather_Venezuela.html).

Lake Maracaibo receives large loads of nutrients from tributaries, sewage discharges, and agricultural sources. The Catatumbo River, which empties into the southeastern region of the lake with a mean flow of about $600 \mathrm{~m}^{3} \mathrm{~s}^{-1}$, contributes about $70 \%$ of the total tributary discharge into the lake (Parri-Pardi 1983). The Catatumbo River receives agricultural and sewage discharges from populations located in Venezuela and Colombia. Phosphorus mining in the mountains around the lake contributes to the tributary phosphorus loading to the lake (Parri-Pardi 1986). Phosphorus is abundant in the lake with epilimnetic phosphate concentrations (in October) ranging from 0.5 to $1.5 \mu \mathrm{M}$ (Parra-Pardi 1983). Livestock development is an important agricultural activity in the Lake Maracaibo basin (e.g., $>2.5 \times 10^{6}$ head of cattle in the western and southwestern areas of the drainage) that contributes nutrients to tributaries. Also, the city of Maracaibo, with a population of approximately one million people, discharges raw sewage directly into the Straits of Maracaibo located on the northern end of the lake. Sewage is also discharged from other smaller population centers around the lake. In addition to nutrient overenrichment, Lake Maracaibo is exposed to pollution from petrochemical industries (Sutton 1974). The lake itself contains about 5,000 oil wells and about $20,000 \mathrm{~km}$ of underwater oil pipes. A large petrochemical processing plant is located in Zulia along the Straits and northeastern portion of the lake (Parri-Pardi 1986).

\section{Methods}

Research vessel and sampling-site characteristics-All field experiments were conducted on the R/V Bergantin, the research vessel of The Instituto para el Control y la Conservacion de la Cuenca del Lago Maracaibo (ICLAM), in conjunction with an ICLAM survey cruise to monitor waterquality and biological characteristics of the lake. Experiments were done in September 1995 when the lake was strongly stratified and internal nutrient cycling rates could be expected to be relatively high. The sampling sites for our experiments, selected from ICLAM stations, are shown in Fig. 1. Five stations were chosen for study to reflect regional differences in nutrient enrichment and phytoplankton composition. Sta. 1, on the northern end of the lake is in the region of sewage discharge from the city of Maracaibo and is more hypereutrophic than the other sites. Stas. 2 and 3 are 


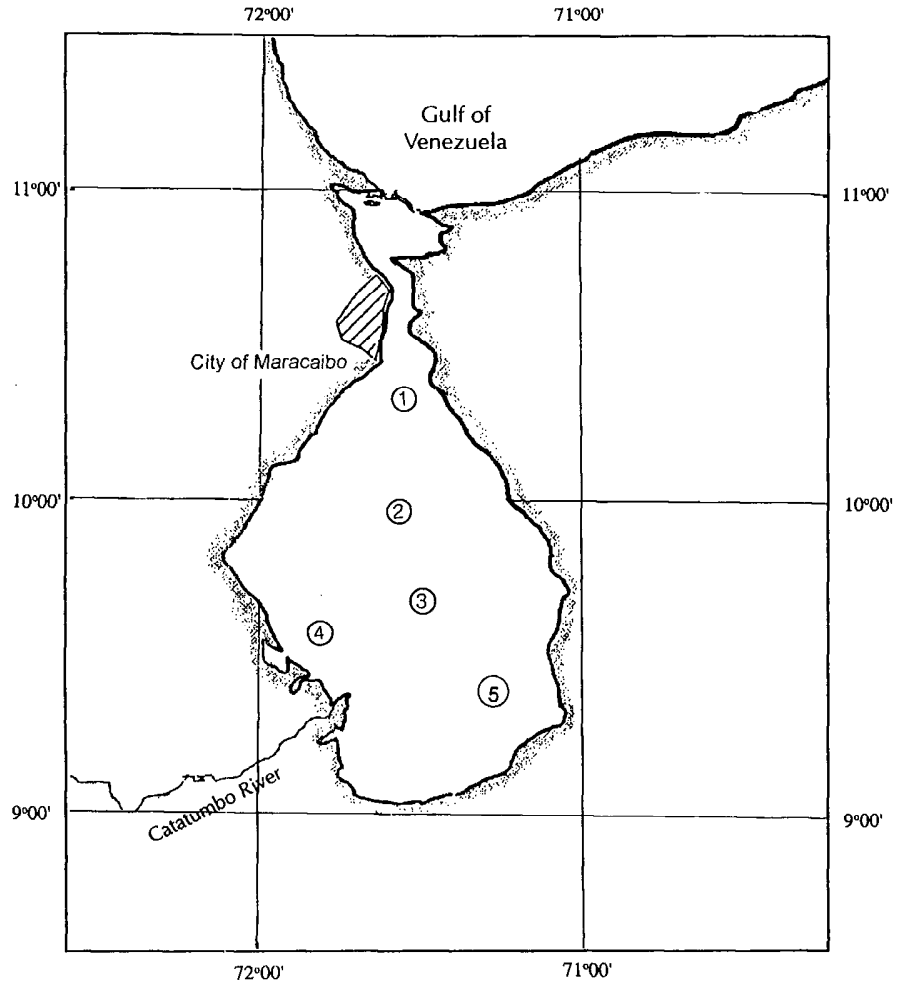

Fig. 1. Location of sampling stations in Lake Maracaibo. Note, Stas. 1, 2, 3, 4, and 5 correspond to ICLAM Stas. NO2, C11, C9, $\mathrm{D} 74$, and D33, respectively.

representative sites for the central part of the lake and Stas. 4 and 5 are southern stations.

Experiments were done at near-surface $(1 \mathrm{~m})$, mid-epilimnion, and near oxycline depths at each station. The midepilimnion sampling depth was $5 \mathrm{~m}$ at all sites except for Sta. 1, the most hypereutrophic site, where it was $3 \mathrm{~m}$. The near-oxycline samples were taken from depths ranging from 9 to $19 \mathrm{~m}$ (Table 1) and were selected as the depths where dissolved oxygen concentrations began to decrease.
Physical, chemical, and microbial-biomass measurements-Physical and chemical characteristics including temperature, dissolved oxygen concentrations, conductivity, salinity, and $\mathrm{pH}$ were measured with a HYDROLAB SURVEYOR II. For Chl measurements, 50 or $100 \mathrm{ml}$ of lake water from various stations and depths were filtered in duplicate onto $47-\mathrm{mm}$ Whatman GF/F filters. The filters were then stored frozen in amber vials and transported back to the National Oceanic and Atmospheric Agency (NOAA) Great Lakes Environmental Research Laboratory. Chlorophyll was extracted by grinding the filters in cold $90 \%$ acetone. After the extracts were held at near $0^{\circ} \mathrm{C}$ for $24 \mathrm{~h}$, the samples were centrifuged, and Chl concentrations were determined with a Turner model $10005 \mathrm{R}$ fluorometer (Strickland and Parsons 1972). Samples for ammonium and nitrate measurements were collected at the mid-epilimnion sampling depths and filtered soon after collection. The filtrates were stored frozen until they were analyzed later at the Great Lakes Environmental Research Laboratory. Ammonium was analyzed fluorometrically (Gardner and St. John 1991) and nitrate (+nitrite) was analyzed by standard autoanalyzer techniques (U.S. Environmental Protection Agency 1974; American Public Health Association 1990).

The numbers and biomass of bacteria and heterotrophic nanoflagellates (HNAN) were determined in an effort to relate them to $\mathrm{N}$ cycling rates. Samples for counting bacteria and HNAN were collected simultaneously with samples for Chl and nutrient cycling experiments. Samples were preserved with $1 \%$ glutaraldehyde (final concentration) and stored at $\sim 4^{\circ} \mathrm{C}$. In the laboratory, they were counted under a Zeiss Labor Lux fluorescence microscope $(\times 1,000$ magnification) on 4'6-diamidino-2-phenylindole (DAPI)-stained preparations (Porter and Feig 1980) using 0.2- $\mu \mathrm{m}$ and $0.8-\mu \mathrm{m}$ black membrane filters for bacteria and flagellates, respectively. DAPI may underestimate bacterial biovolumes and numbers, as compared to acridine orange (AO), due to an insufficient amount of DNA in some bacterial cells and by the lack of it in the cell wall (Suzuki et al. 1993). However, the DAPI stain was chosen because we felt that the AO technique would

Table 1. Physical/chemical characteristics of the sampling sites in Lake Maracaibo during R.V. Bergantin cruise in Autumn 1995.

\begin{tabular}{|c|c|c|c|c|c|c|c|c|}
\hline $\begin{array}{c}\text { Sta. ID } \\
\text { (depth m) }\end{array}$ & Date 1995 & $\begin{array}{l}\text { Secchi depth } \\
\text { (m) }\end{array}$ & $\begin{array}{l}\text { Depth } \\
\text { (m) }\end{array}$ & $\begin{array}{c}\text { Temperature } \\
\left({ }^{\circ} \mathrm{C}\right)\end{array}$ & $\begin{array}{c}\text { Dissolved } \\
\text { oxygen } \\
\left(\mathrm{mg} \mathrm{liter}^{-1}\right)\end{array}$ & $\begin{array}{l}\text { Conductivity } \\
\left(\mathrm{ohm}^{-1}\right)\end{array}$ & $\begin{array}{l}\text { Salinity } \\
(\% o)\end{array}$ & $\mathrm{pH}$ \\
\hline \multirow{2}{*}{$1(15 \mathrm{~m})$} & 28 Sep & 1.2 & 1 & 31.17 & 8.22 & 7.67 & 3.9 & 8.20 \\
\hline & & & 9 & 30.89 & 6.52 & 7.90 & 4.0 & 7.97 \\
\hline \multirow{2}{*}{$2(27 \mathrm{~m})$} & $26 \mathrm{Sep}$ & 2.0 & 1 & 31.17 & 7.31 & 8.39 & 4.3 & 7.70 \\
\hline & & & 5 & 30.45 & 6.98 & 8.41 & 4.3 & 7.67 \\
\hline \multirow{2}{*}{$3(27 \mathrm{~m})$} & & & 5 & 30.32 & 6.45 & 8.46 & 4.4 & 7.46 \\
\hline & & & 15 & 30.19 & 5.73 & 8.47 & 4.4 & 7.25 \\
\hline \multirow{3}{*}{$4(28 \mathrm{~m})$} & $24 \mathrm{Sep}$ & 2.5 & 1 & 30.64 & 6.64 & 8.43 & 4.3 & 7.75 \\
\hline & & & 5 & 30.62 & 6.63 & 8.43 & 4.3 & 7.75 \\
\hline & & & 13 & 30.58 & 6.30 & 8.46 & 4.4 & 7.70 \\
\hline $5(27 \mathrm{~m})$ & 25 Sep & 2.8 & 1 & 30.35 & 6.82 & 7.50 & 3.8 & 7.72 \\
\hline
\end{tabular}


likely have overestimated bacterial biomass in the particlerich Lake Maracaibo samples by nonspecifically staining detrital material, including dead bacterial cells with DNA removed (Suzuki et al. 1993). Bacterial biovolumes were converted to carbon using allometric equations and then an average was calculated (Norland 1993). Protozoan biomass was determined as specified by Putt and Stoecher (1989). Microbial biomass was also converted to $\mathrm{N}$ based on assumed $\mathrm{C}: \mathrm{N}$ ratios of 5 for bacteria and protozoa (Nakano 1994).

Nitrogen cycling experiments-Isotope dilution experiments with high-level additions (50 $\mu \mathrm{M}$ final concentration) of ${ }^{15} \mathrm{NH}_{4}^{+}$were conducted to evaluate potential uptake and regeneration rates for ammonium and to examine the effects of light conditions on potential rates in this hypereutrophic system. The high level additions were useful for Sta. 1 samples because low levels of the ${ }^{15} \mathrm{NH}_{4}^{+}$substrate would likely have been depleted during sample incubation and thereby reduced the accuracy of measurements. However, the relatively small changes in isotope ratios during the incubations caused by the high level additions increased the error-tosignal ratios for potential uptake and regeneration rates as compared to similar incubations with lower level additions (e.g., $4 \mu \mathrm{M}$; Gardner et al. 1997).

Isotope dilution cxperiments were conducted in different types of incubation vessels to create a variety of light conditions. For surface waters, triplicate incubation experiments were conducted in (1) cloudy $60-\mathrm{ml}$ polypropylene syringes with one screen $(53 \%$ reduction in light intensity $=$ light treatments), (2) polypropylene syringes covered with duct tape (dark treatments), (3) 70-ml polystyrene culture bottles with one screen (45\% reduction in light intensity), and (4) quartz tubes (full light intensity). The light absorption characteristics of the polypropylene syringes and polystyrene culture bottles, respcctively, were observed by placing a portion of wall from each vessel in a Perkin-Elmer Lambda 6 UV/visible spectrophotometer and running a scan over the wavelength range of 300-700 $\mathrm{nm}$. In contrast to the polystyrene and quartz tubes, the syringe incubation vessels did not contain open headspacc above the sample water. Sampling from fixed-volume bottles typically creates headspace unless whole bottles are sacrificed at each sampling point (Pakulski et al. 1995) or if time-point sample water is replaced in the incubation bottles (Gardner et al. 1994). Triplicate experiments on unfiltered mid-epilimnetic water were conducted in polypropylene syringes with three layers of dark nylon window screen (81\% reduction in light intensity) and in dark syringes, respectively. Near-oxycline samples were incubated in triplicate in dark syringes only.

In addition to these experiments on unfiltered water, duplicate isotope dilution experiments were done on filtered $(0.2-\mu \mathrm{m}$ pore size nylon) surface waters to examine photochemical regeneration and/or oxidation of ammonium by sunlight. The ends of the quartz bottles were placed in a plastic holder constructed to maintain the bottles in a horizontal position at the incubator water surface. Incident light intensities were measured five to seven times during each incubation using a LICOR LI-1000 data logger equipped with a LICOR Quantum flat plate sensor that was positioned on deck near the incubator tank.
The experimental protocol for isotope dilution experiments involved adding $60 \mathrm{ml}$ of water to the incubation vessels, spiking with ${ }^{15} \mathrm{NH}_{4}^{+}$(from a standard concentrate of 10 $\mathrm{mM}{ }^{15} \mathrm{NH}_{4} \mathrm{Cl}$ ), mixing thoroughly, and sampling shortly after spiking and again after a measured interval of about $4 \mathrm{~h}$. The experimental containers were incubated in an outdoor incubator constructed by having lake water continuously pumped into an overflowing chest on the top deck of the research vessel. Temperature of the incubator ranged from 30 to $33.5^{\circ} \mathrm{C}$ during incubations, as compared to surface water temperature that typically ranged from 30 to $32^{\circ} \mathrm{C}$. At Sta. 5, samples were also taken after an additional incubation period (T-2) of about $5 \mathrm{~h}$ to observe the pattern of ammonium concentrations and isotope ratios over a more extended period. Rate comparisons among stations are all made from measurements taken over the first incubation intervals.

Samples were collected from the syringe incubation vessels by passing water directly through $0.2-\mu \mathrm{m}$ pore-size nylon filters (Rainin) attached to the syringes. Samples were removed from the polystyrene culture bottle and the quartz tube incubation vessels with a rinsed 10 -ml syringe via a clean needle and then passed through a syringe filter. The first $3 \mathrm{ml}$ of filtrate from each sample rinsed the filter and was discarded. The next $7 \mathrm{ml}$ of filtrate was placed into a clean vial (Wheaton 224884) and frozen for later analysis of ammonium concentration and atom $\%{ }^{15} \mathrm{~N}-\mathrm{NH}_{4}^{+}$by high-performance liquid chromatography (HPLC; Gardner et al. $1995 a$ ) at the NOAA Great Lakes Environmental Research Laboratory. With this method, the atom $\%$ of ${ }^{15} \mathrm{~N}$ in the ammonium was determined directly in solution by calibrating the shift in ammonium retention time caused by the presence of ${ }^{15} \mathrm{NH}_{4}^{+}$relative to that for an internal standard of natural abundance ammonium prepared in mobile phase buffer. Ammonium concentration was determined from the same chromatograms by comparing peak area of the sample ammonium to the peak area of the internal standard of ammonium. Potential uptake and regeneration rates were calculated from changes in ammonium concentrations and isotope ratios over time using the Blackburn/Caperon model (Blackburn 1979; Caperon et al. 1979).

\section{Results}

Physical and chemical characteristics, Chl, and ammonium concentrations-Temperatures of the water during sampling (usually about mid-day) ranged from 30.2 to $31.2^{\circ} \mathrm{C}$ (Table 1). As previously described in detail (e.g., Parri-Pardi 1983), dissolved oxygen concentrations and $\mathrm{pH}$ generally decreased with depth in the lake, whereas conductivity and salinity increased (Table 1). Dissolved oxygen concentrations in near-surface waters ranged from 6.4 to 8.2 mg liter ${ }^{-1}$ (Table 1), whereas oxygen was always depleted in bottom waters (data not shown).

Chl concentrations ranged from $3.5 \mu \mathrm{g} \mathrm{liter}^{-1}$ to $22 \mu \mathrm{g}$ liter $^{-1}$ (Table 2). Sta. 1, located in the region where the Straits connect to the lake and in the vicinity of the sewage outflow discharge from the city of Maracaibo, had the highest surface Chl levels and dissolved oxygen concentrations of the sites examined (Tables 1 and 2). Chl concentrations 
Table 2. Chlorophyll concentration, biomass of bacteria, and HNAN and their ratio, PN concentration, and percentage of PN present as bacterial $\mathrm{N}$ (Bact-N) and as HNAN-N, respectively, in Lake Maracaibo. Bact-N and HNAN-N were calculated based on a C:N ratio of 5.

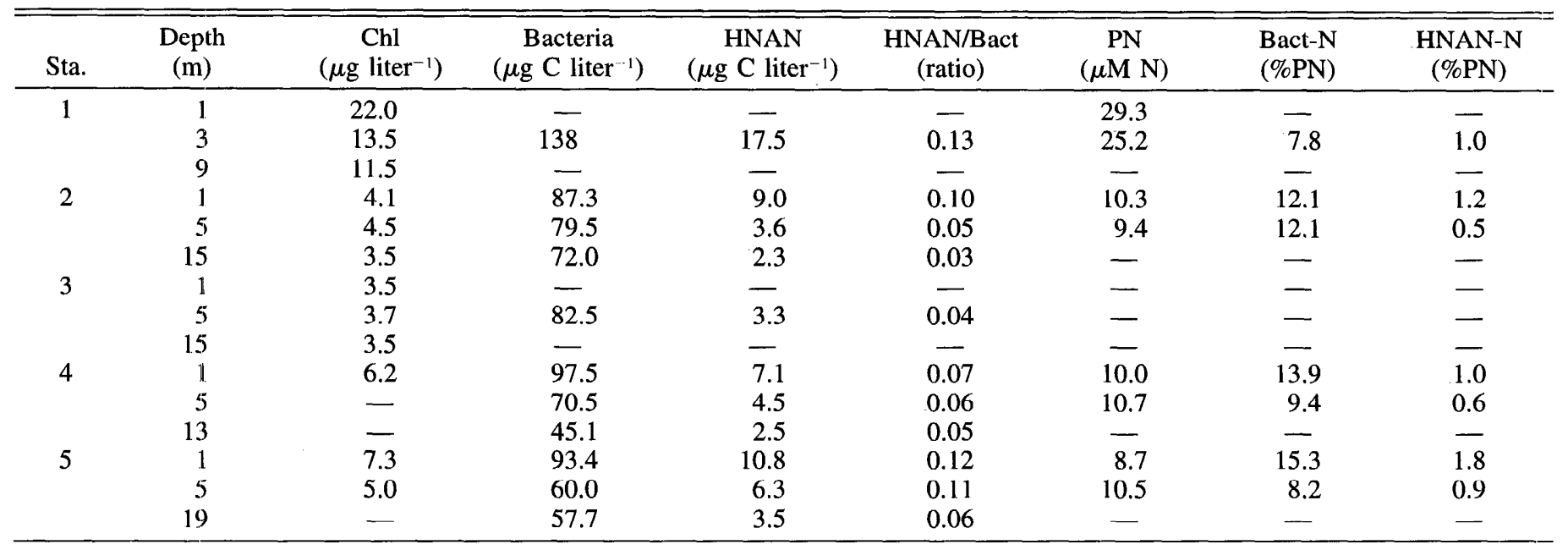

at Stas. 2 and 3, located in the central region of the lake, were relatively low (3-4 $\mu$ liter $^{-1}$ ) and concentrations at Stas. 4 and 5, located in the southwestern and southeastern part of the lake north and west of the Catatumbo River inflow, respectively, were intermediate $\left(6-7 \mu \mathrm{g} \mathrm{liter}^{-1}\right)$ in surface waters. Chl concentrations decreased with depth at Sta. 1 but remained approximately constant with depth at other stations (Table 2). Particulate N (PN) concentrations correlated significantly ( $r=0.95, P<0.01)$ with Chl concentrations for sites where both were measured. Abundance of bacteria ranged from 1.0 to $9.1 \times 10^{6}$ cells $\mathrm{ml}^{-1}$ as compared

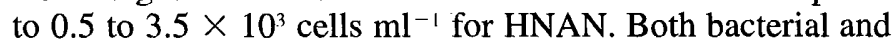
protozoan densities were highest in surface waters at the three stations where depth profiles were examined. The maximum concentrations of these microorganisms were found at Sta. 1 that was sampled only from the $3-\mathrm{m}$ depth. The biomass of bacteria and HNAN followed similar patterns, ranging from 45 to $138 \mu \mathrm{g} \mathrm{C}$ liter $^{-1}$ and 2.3 to $17.5 \mu \mathrm{g} \mathrm{C}$ liter $^{-1}$, respectively (Table 2). In contrast to October 1994, when ammonium levels averaged about $4 \mu \mathrm{M}$ (H. Bootsma unpubl. data), ammonium and nitrate levels in the water were consistently low $(<1 \mu \mathrm{M})$ when measured on freshly filtered samples at 3-5-m depth in this study (data not shown). PN concentrations ranged from 9 to $29 \mu \mathrm{M}$ at the different sites (Table 2). Estimated bacterial N accounted for about 8-15\% of the total PN, whereas HNAN-N constituted only $0.5-$ $1.8 \%$ of the total PN (Table 2).

Nitrogen cycling rates-Potential uptake and regeneration rates of ammonium were measured under several different light conditions in surface (1-m) waters, under dim-light and dark conditions at mid-depth $(3-5 \mathrm{~m})$, and under dark conditions for deeper waters $(9-19 \mathrm{~m})$. For comparison of potential rates at different sites and depths, we emphasize rates measured in the polypropylene syringes. These vessels were the only ones that were used at all three depths. Surfacesample potential uptake rates were higher in them than in the quartz tubes or polystyrene culture bottles (Table 3 ).

Time course patterns over two time intervals for ammo- nium concentrations and atom $\%{ }^{15} \mathrm{~N}-\mathrm{NH}_{4}^{\prime}$ in light and dark incubations at Sta. 5 are shown in Fig. 2. The decreases in atom $\%{ }^{15} \mathrm{~N}-\mathrm{NH}_{4}^{+}$were relatively linear over time for most of these treatments, but ammonium concentrations decreased more during the second interval than during the first interval in the respective treatments. At this station, rates of isotope dilution were higher in the light than in the dark in both the surface and mid-depth water. This observation indicated that the calculated mean regeneration rates were more rapid in the light than in the dark; however, the differences in rates were not statistically significant (Table 3 ).

In near-surface waters, ammonium cycling rates were highest at Sta. 1 (Tables 3,4), where Chl concentrations were also highest (Table 2). Potential uptake rates at this station averaged 7-8 $\mu \mathrm{M} \mathrm{h}^{-1}$ (Table 3) as compared to ammonium regeneration rates of $1.7-2.0 \mu \mathrm{M} \mathrm{h}^{-1}$ (Table 4). Mean potential uptake rates at Stas. 2 and 3 ranged between 4.1 and $4.7 \mu \mathrm{M} \mathrm{h}^{-1}$ and were higher than those observed at Stas. 4 and 5 (0.8-1.4 $\mu \mathrm{M} \mathrm{h}^{-1}$; Table 3) even though Chl levels were higher at the more southern stations (Table 2). In contrast, all four of these stations showed comparable regeneration rates (0.06-0.7 $\mu \mathrm{M} \mathrm{h}^{-1}$; Table 4) that were lower than those at Sta. 1. Differences between light and dark treatments were not significant (i.e., overlapping SE) at any of the stations examined (Table 4). Dark rates were not obtained at Sta. 4 because of analytical problems.

Chl-specific potential uptake rates were higher at the midlake sites (Stas. 2 and 3) than at either the most nutrientenriched Sta. 1 site or the southern sites (Stas. 4 and 5; Fig. 3 ). In contrast to the pattern for the community ammonium regeneration rates, where rates were much higher at Sta. 1 than at the other stations, Chl-specific regeneration rates in surface waters were comparable among the different stations (Fig. 4).

Nitrogen cycling rates at mid-depths $(3-5 \mathrm{~m})$ were lower but comparable to those observed in near-surface waters, except for ammonium regeneration rates at Sta. 1 that were less than one half of the rates observed in the 1-m samples (Tables 3, 4). Although potential uptake rates were higher at 
Table 3. Potential ammonium uptake rates $\left(\mu \mathrm{M} \mathrm{h}^{-1}\right)$ in Lake Maracaibo water samples collected from different sites and depths and incubated under different light conditions in September 1995. PPS-L, polypropylene syringe with 53\% (1-m samples) or $81 \%$ (3- or 5-m samples) blockage of light intensity, respectively; PPS-D, darkened polypropylene syringe; polystyrene, polystyrene tissue culture bottle with $45 \%$ blockage of light intensity; quartz, quartz tubes.

\begin{tabular}{|c|c|c|c|c|c|}
\hline Sta. & ID & PPS-L & PPS-D & Polystyrene & Quartz \\
\hline \multirow[t]{3}{*}{1} & $(1 \mathrm{~m})$ & $8.30 \pm 0.45$ & $6.95 \pm 0.71$ & $2.56 \pm 0.38$ & $2.12 \pm 0.23$ \\
\hline & $(3 \mathrm{~m})$ & $5.41 \pm 0.41$ & - & - & - \\
\hline & $(9 \mathrm{~m})$ & - & $5.26 \pm 0.17$ & - & - \\
\hline \multirow[t]{3}{*}{2} & (1 m) & $4.68 \pm 0.90$ & $4.26 \pm 0.23$ & $1.53 \pm 0.29$ & $-0.09 \pm 0.17$ \\
\hline & $(5 \mathrm{~m})$ & $3.33 \pm 0.43$ & $3.35 \pm 0.02$ & - & - \\
\hline & $(15 \mathrm{~m})$ & - & $2.64 \pm 0.25$ & - & - \\
\hline \multirow[t]{3}{*}{3} & $(1 \mathrm{~m})$ & $4.59 \pm 0.15$ & $4.10 \pm 0.54$ & $0.09 \pm 0.23$ & $0.43 \pm 0.19$ \\
\hline & $(5 \mathrm{~m})$ & $3.57 \pm 0.14$ & $3.91 \pm 0.15$ & - & - \\
\hline & $(15 \mathrm{~m})$ & - & $3.99 \pm 0.44$ & - & - \\
\hline \multirow[t]{3}{*}{4} & $(1 \mathrm{~m})$ & $1.00 \pm 0.33$ & - & $0.014 \pm 0.05$ & $0.30 \pm 0.05$ \\
\hline & $(5 \mathrm{~m})$ & $0.16 \pm 0.92$ & $-0.46 \pm 0.72$ & - & - \\
\hline & $(13 \mathrm{~m})$ & - & $-0.05 \pm 0.24$ & - & - \\
\hline \multirow[t]{3}{*}{5} & $(1 \mathrm{~m})$ & $1.39 \pm 0.39$ & $0.76 \pm 0.31$ & $0.35 \pm 0.10$ & $-0.03 \pm 0.09$ \\
\hline & $(5 \mathrm{~m})$ & $1.05 \pm 0.28$ & $0.59 \pm 0.31$ & - & - \\
\hline & $(19 \mathrm{~m})$ & - & $0.21 \pm 0.21$ & - & - \\
\hline
\end{tabular}

mid-depth at Sta. 1 than at the other mid-depth stations, the calculated mean ammonium regeneration rate $\left(0.57 \mu \mathrm{M} \mathrm{h}^{-1}\right)$ was near the range of those observed at the other mid-depth stations $\left(<0-0.52 \mu \mathrm{M} \mathrm{h}^{-1}\right.$; Table 4). As in the 1-m samples, mid-depth ammonium uptake rates at Stas. 2 and 3 (3.3-3.9 $\left.\mu \mathrm{M} \mathrm{h}^{-1}\right)$ were intermediate between the rates observed at Sta. $1\left(5.4 \mu \mathrm{M} \mathrm{h}^{-1}\right)$ and Sta. $5\left(0.6-1.0 \mu \mathrm{M} \mathrm{h}^{-1}\right)$. Uptake rates were relatively low at Sta. 4 (Table 3 ).

Nitrogen cycling rates at the near-oxycline depths were similar or lower than those observed at mid-depths. As was true for the upper two depths, the highest rates for both potential uptake and regeneration occurred at Sta. 1 (Tables 3, 4). Substantial uptake rates were also observed at Stas. 2 and 3, but, in contrast, potential uptake rates were approximately zero at near-oxycline depths at Stas. 4 and 5. In comparison, regeneration rates were not statistically different from zero at the lowest depth for all sites except for Sta. 1 where the mean ammonium regeneration rate was $0.8 \pm 0.07$ $\mu \mathrm{M} \mathrm{h}^{-1}$ (Table 4).

To evaluate organisms and mechanisms responsible for $\mathrm{N}$ cycling, potential uptake and regeneration rates for ammonium were compared to concentration of $\mathrm{Chl}\left(\mu \mathrm{g} \mathrm{liter}^{-1}\right)$ and biomass of bacteria and heterotrophic nanoflagellates (HNAN), both expressed as ( $\mu \mathrm{g} \mathrm{C}$ liter ${ }^{-1}$; Table 2$)$. Potential uptake rates did not correlate with $\mathrm{Chl}$ concentrations, as may be expected from the differences noted above in Chlspecific uptake rates among stations. The ammonium regeneration rates tended to increase with $\mathrm{Chl}$ concentrations, but the relationship was weak $(r=0.6, P=0.11)$. However, ammonium regeneration rates were highly correlated $(r=$ $0.77, P<0.01$ ) with the ratio of HNAN to bacterial carbon. Bacterial and HNAN biomass (Table 2) were proportional ( $r$ $=0.86, P<0.001)$, and both increased directly with $\mathrm{Chl}$ concentrations $(r=0.91$ and 0.89 , respectively, $P<0.01)$. The ratio of bacterial numbers per flagellate cell ranged between $2.6 \times 10^{3}$ and $1.2 \times 10^{4}$.
Effects of light on $N$ cycling rates-Potential uptake rates were highest in the light and dark syringes but were consistently significantly lower in the quartz bottles and clear polystyrene culture bottles (Table 3). Comparison of light absorption spectra of walls of the two types of plastic incubation containers (Fig. 5) showed that the polypropylene syringe wall absorbed increasingly more light with decreasing wavelength over the wavelengths of 700 to $300 \mathrm{~nm}$. By comparison, the polystyrene culture bottle wall absorbed less than $6 \%$ of the light through the whole visible region of the spectra but showed increasing absorbance with decreasing wavelength in the ultraviolet region (Fig. 5). Another difference in the incubation containers was that, in contrast to the other two types of vessels, the syringes did not contain headspace.

The effects of sunlight in photochemically regenerating ammonium from DON was examined by conducting duplicate isotope dilution experiments on surface lake water that had first been filtered through a $0.2-\mu \mathrm{m}$ pore-size filter. Mean photochemical regeneration rates of about $0.2 \mu \mathrm{M} \mathrm{h}^{-1}$ were observed in filtered waters from the three sites (Stas. 1, 2, and 5) that were exposed to bright sunlight (Table 5). By comparison, total community ammonium regeneration rates on unfiltered water from the same three stations ranged from 0.50 to $1.69 \mu \mathrm{M} \mathrm{h}^{-1}$ (Table 4). Filtered water from Sta. 3, that was incubated under low light conditions, caused by cloudy/rainy meteorological conditions, yielded a calculated photochemical regeneration rate $\left(-0.07 \mu \mathrm{M} \mathrm{h}^{-1}\right)$ that was not distinguishable from zero. By comparison, a total community regeneration rate of $0.53 \mu \mathrm{M} \mathrm{h}^{-1}$ was measured in the polyethylene syringes. Mean photochemical oxidation rates for ammonium ranged from 0.06 to $0.13 \mu \mathrm{M} \mathrm{h}^{-1}$ for the stations with intensive sunlight as compared to $0.002 \mu \mathrm{M}$ $\mathrm{h}^{-1}$ for the samples incubated under cloudy conditions, but SE for all of the individual means overlapped with zero (Table 5).

To increase the degrees of freedom and improve statistical 

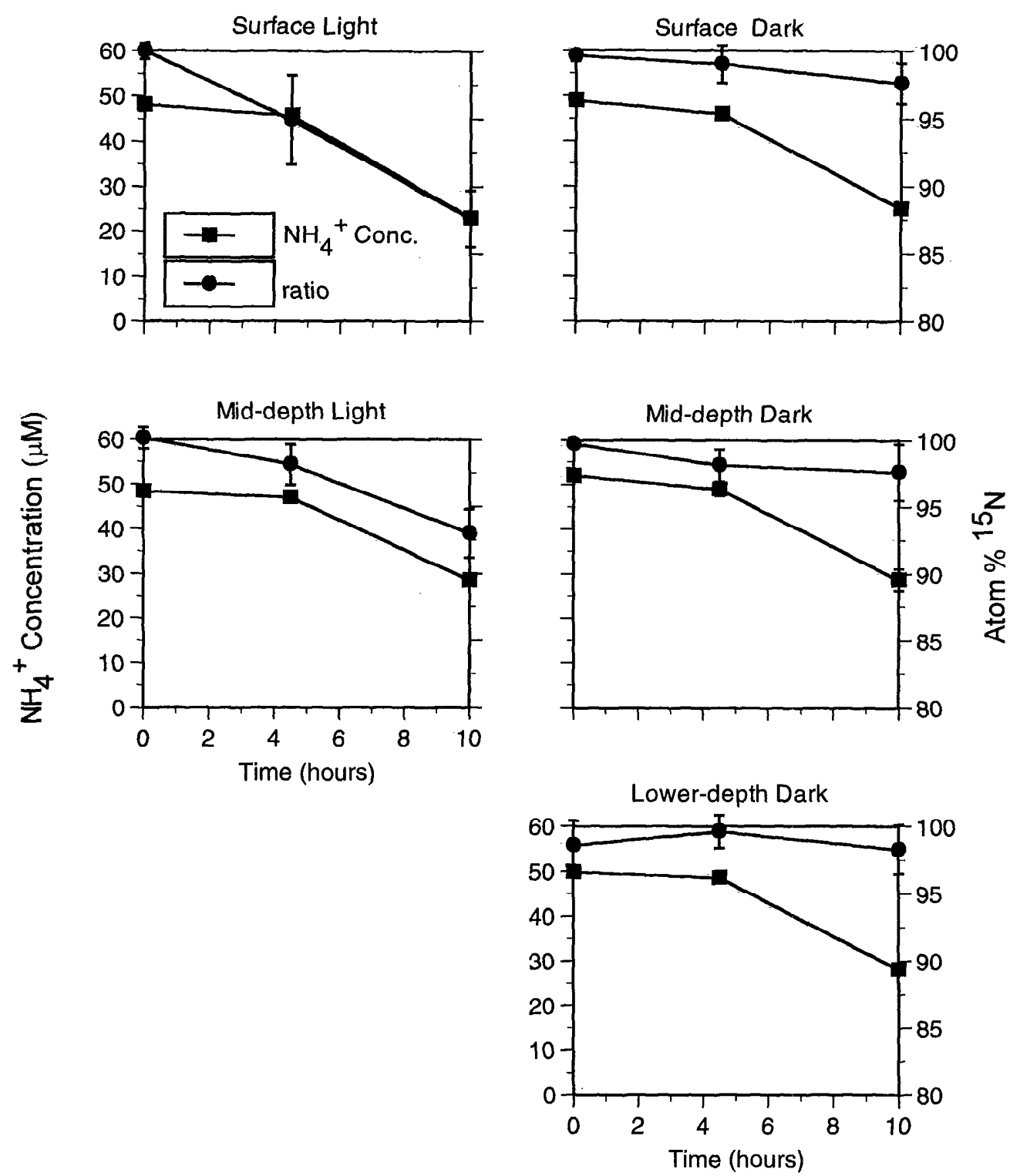

Fig. 2. Time-course patterns of ammonium concentrations and isotope ratios for light and dark bottle experiments at Sta. 5 in Lake Maracaibo. Depths of surface mid-depth, and lower depth samples were $1 \mathrm{~m}, 5 \mathrm{~m}$, and $19 \mathrm{~m}$, respectively.

evaluation of the photochemical regeneration and oxidation data, we grouped data from various stations. This approach yielded a mean photochemical production of ammonium from DON of $0.21+0.08 \mu \mathrm{M} \mathrm{h}^{-1}(n=6)$ on the three bright days or an average of $0.14 \pm 0.07 \mu \mathrm{M} \mathrm{h}^{-1}(n=8)$ if results from the cloudy day are included. These values are equal to $22 \%$ (bright days) or $16 \%$ (including cloudy day) of the mean community regeneration rates on unfiltered surface samples that were measured in polypropylene syringes at the same stations (Table 4). Interestingly, they account for $31 \%$ of the mean surface-water community regeneration rates measured in the quartz tubes on bright days or $23 \%$ if results from the cloudy day are included. The mean ammonium removal rate that could have resulted from photochemical oxidation of ammonium in filtrates from the three stations was $0.09 \pm 0.10 \mu \mathrm{M} \mathrm{h}^{-1}(n=6)$, i.e., a value not distinguishable from zero, as compared to a calculated mean community uptake rate of $4.78 \pm 1.04 \mu \mathrm{M} \mathrm{h}^{-1}(n=9)$. Thus, some ammonium was apparently photochemically produced from DON, but significant removal of ammonium through photochemical oxidation by sunlight was not decisively demonstrated.

\section{Discussion}

Lake Maracaibo is an interesting system to study $\mathrm{N}$ cycling rates and the effects of light because it is a hypereutrophic tropical lake where solar intensity is quite high and surface water temperature typically ranges between 30 and $32^{\circ} \mathrm{C}$. Nitrogen is the nutrient that is considered to be most 
Table 4. Potential ammonium regeneration rates $\left(\mu \mathrm{M} \mathrm{h}^{-1}\right)$ in Lake Maracaibo water samples collected from different sites and depths and incubated under selected light conditions in September 1995. Abbreviations defined in Table 2.

\begin{tabular}{|c|c|c|c|c|c|}
\hline Sta. & ID & PPS-L & PPS-D & Polystyrene & Quartz \\
\hline \multirow[t]{3}{*}{1} & $(1 \mathrm{~m})$ & $1.69 \pm 0.37$ & $2.00 \pm 0.37$ & $0.55 \pm 0.18$ & $1.25 \pm 0.29$ \\
\hline & $(3 \mathrm{~m})$ & $0.57 \pm 0.30$ & - & - & - \\
\hline & $(9 \mathrm{~m})$ & - & $0.81 \pm 0.07$ & & - \\
\hline \multirow[t]{3}{*}{2} & $(1 \mathrm{~m})$ & $0.50 \pm 0.45$ & $0.51 \pm 0.19$ & $1.01 \pm 0.54$ & $-0.26 \pm 0.15$ \\
\hline & $(5 \mathrm{~m})$ & $0.37 \pm 0.26$ & $0.52 \pm 0.07$ & - & - \\
\hline & $(15 \mathrm{~m})$ & - & $0.12 \pm 0.16$ & - & - \\
\hline \multirow[t]{3}{*}{3} & $(1 \mathrm{~m})$ & $0.53 \pm 0.18$ & $0.06 \pm 0.33$ & $-0.03 \pm 0.25$ & $0.40 \pm 0.20$ \\
\hline & $(5 \mathrm{~m})$ & $-0.16 \pm 0.08$ & $0.46 \pm 0.14$ & - & - \\
\hline & $(15 \mathrm{~m})$ & - & $0.27 \pm 0.29$ & - & - \\
\hline \multirow[t]{3}{*}{4} & $(1 \mathrm{~m})$ & $0.46 \pm 0.18$ & - & $-0.017 \pm 0.05$ & $0 \pm 0$ \\
\hline & $(5 \mathrm{~m})$ & $0.04 \pm 0.93$ & $-1.17 \pm 0.65$ & - & - \\
\hline & $(13 \mathrm{~m})$ & - & $0.15 \pm 0.11$ & - & - \\
\hline \multirow[t]{3}{*}{5} & $(1 \mathrm{~m})$ & $0.72 \pm 0.37$ & $0.15 \pm 0.28$ & $0.10 \pm 0.12$ & $0.02 \pm 0.10$ \\
\hline & $(5 \mathrm{~m})$ & $0.28 \pm 0.17$ & $-0.11 \pm 0.23$ & - & - \\
\hline & $(19 \mathrm{~m})$ & - & $-0.15 \pm 0.30$ & - & - \\
\hline
\end{tabular}

limiting to phytoplankton, and concentrations of ammonium are sometimes very low. For examplc, ammonium concentrations were less than $1 \mu \mathrm{M}$ at the four stations where it was measured, whereas PN was greater than $9 \mu \mathrm{M}$ at all stations. Under these conditions, rapid $\mathbf{N}$ recycling should occur in the oxygenated part of the water column as well as in the anoxic hypolimnion and at the sediment-water interface.

Our $\mathrm{N}$ cycling measurements were focused on the oxygenated portion of the water column. Regeneration of ammonium in the oxygenated region may be of particular importance as an $\mathrm{N}$ source to phytoplankton because redox conditions appear to be ideal for nitrification/denitrification to occur at the oxygen transition zone. Nitrification/denitrification reactions in this region may prevent ammonium that

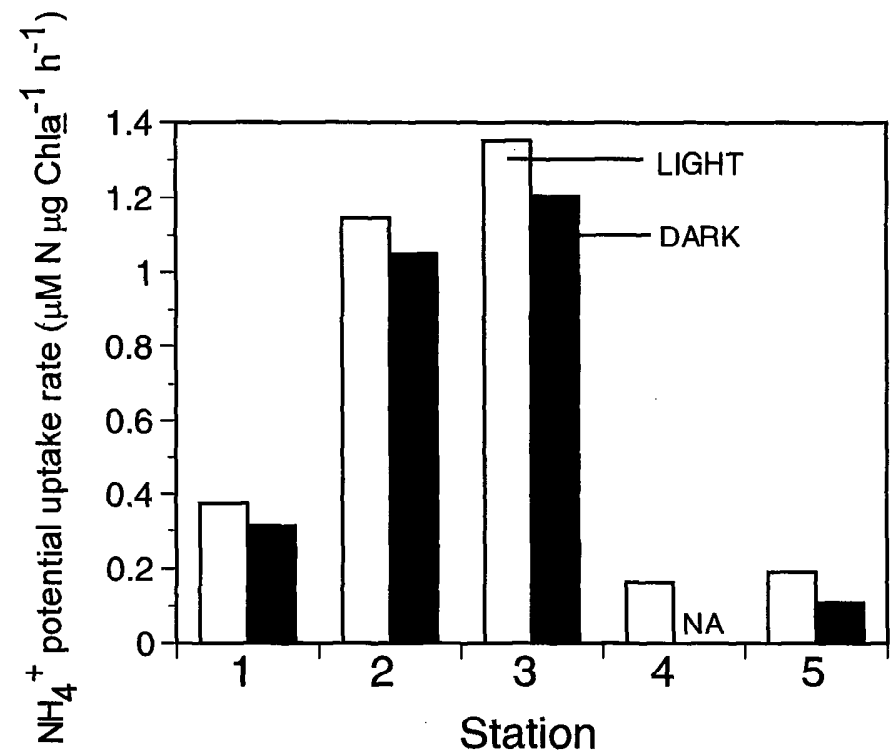

Fig. 3. Chl-specific potential uptake rates for ammonium in light and dark bottles at five stations in Lake Maracaibo. NA = not analyzed. is regenerated below this zone from becoming available to the phytoplankton except for when wind-driven events cause pulses of hypolimnetic nutrients to be delivered into the photic zone. This $\mathrm{N}$ sink, along with high phosphate concentrations, could potentially be a cause of $\mathrm{N}$ limitation in the lake. The observation that natural ammonium and nitrate concentrations were consistently low at our sample sites suggests that $\mathrm{N}$ was in high demand at all the stations that we examined in Lake Maracaibo.

The potential recycling rates that we observed for $\mathrm{N}$ are, to our knowledge, among the highest that have been reported for natural waters (e.g., Selmer 1988; Lipschultz et al. 1986; Morrissey and Fisher 1988; Hanson et al. 1990; Cotner and Gardner 1993; Gardner et al. 1995b). Community ammonium uptake and regeneration rates were particularly high at Sta. 1. Rates at other sites were comparable to those observed in tropical Lake Calado (Morrissey and Fisher 1988). In agreement with previous conclusions for Lake Calado

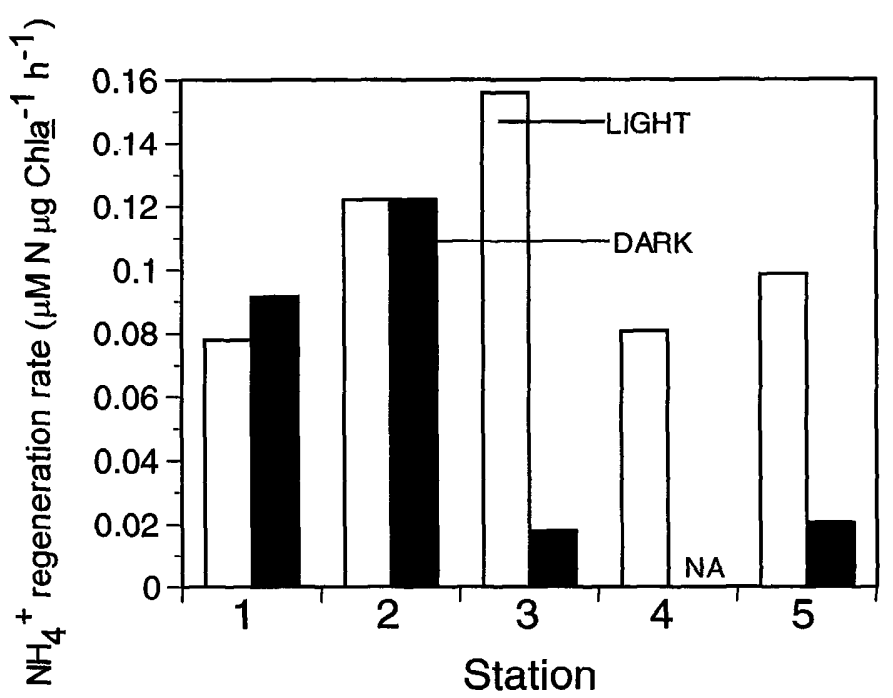

Fig. 4. Chl-specific ammonium regencration rates in light and dark bottles at five stations in Lake Maracaibo. NA $=$ not analyzed. 


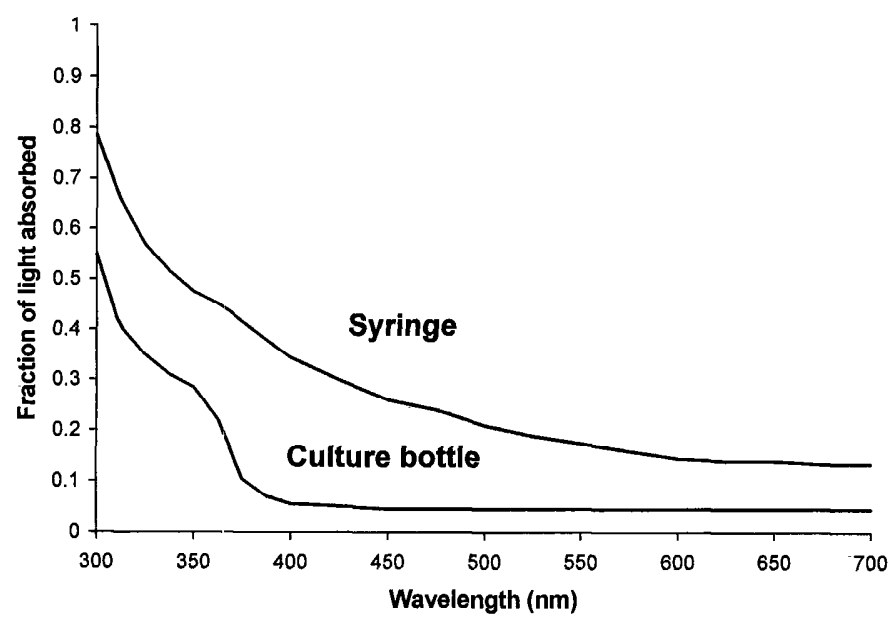

Fig. 5. Wavelength spectrum for fraction of light absorbed by container walls of polypropylene syringes and polystyrene culture bottles that were used for ${ }^{15} \mathrm{NH}_{4}^{+}$isotope dilution experiments.

(Fisher et al. 1988), these results support our hypothesis that pelagic ammonium regeneration is a major $\mathbf{N}$ supply mechanism in Lake Maracaibo. This result is not surprising because, as mentioned above, Lake Maracaibo is hypereutrophic, has a mean temperature of $\sim 30^{\circ} \mathrm{C}$, and has very high primary production rates (Sutton 1974). The combination of low ambient concentrations of available $\mathrm{N}$ with high PN concentrations and high $\mathrm{N}$ cycling rates indicate that recycling processes are an important source of usable $\mathbf{N}$ to phytoplankton in the lake. This observation agrees with the hypothesis that elemental cycles are dominantly under biological control in tropical lakes (Kilham and Kilham 1990). Similar conclusions were drawn for phosphorus in Lake Maracaibo by comparing the ratio of biomass $\mathrm{P}$ to that in the dissolved component (Redfield 1958).

Bacteria and HNAN counts were not obtained at the 1-m depth at Sta. 1 where $\mathrm{N}$ cycling rates were highest, but their abundance at the 3-m depth was higher than it was at any other station. Abundant populations of planktonic protozoa and other microorganisms have been found in tropical lakes (Hecky and Kling 1981; Lewis 1985; Beaver and Crisman 1982; Finlay et al. 1987). The central role of the microbial food web in $\mathrm{N}$ recycling has been reported for different temperate pelagic environments (Caron and Goldman 1990; Haga et al. 1995; Miller et al. 1995; Selmer et al. 1993; Suzuki et al. 1996) and was suggested from size-fractionation studies in Lake Calado (Fisher et al. 1988). This conclusion agrees with the high correlation that we observed between $\mathrm{N}$ cycling rates and the HNAN : bacterial biomass ratio, a variable that potentially characterizes the relative proportion of bacterial biomass transferred to the next trophic level for growth and metabolism. The high metabolic rates of protozoa (Fenchel 1987) could compensate for their modest contribution to $\mathrm{PN}$ in this study. Bacterial numbers per nanoflagellate cell were considerably higher than average values reported in the literature (Sanders et al. 1992 and references therein). This observation suggests that there is a strong predation pressure on HNAN in Lake Maracaibo.

Except for a general tendency for rates to decrease with
Table 5. Light intensity and photochemical ammonium regeneration and removal rates in $0.2-\mu \mathrm{m}$ pore-size-filtered near-surface lake water that had been fortified with ${ }^{15} \mathrm{NH}_{4}{ }^{+}(50 \mu \mathrm{M})$ and incubated in quartz tubes under natural sunlight for about $4 \mathrm{~h}$. Light intensities were measured five to seven times during the course of each incubation.

\begin{tabular}{cccc}
\hline \hline Sta. & $\begin{array}{c}\text { Light intensity } \\
\left(\mu \mathrm{E} \mathrm{m}^{-2} \mathrm{~s}^{-1}\right)\end{array}$ & $\begin{array}{c}\text { Regeneration } \\
\text { rates } \pm \mathrm{SE} \\
\left(\mu \mathrm{M} \mathrm{h} \mathrm{h}^{-1}\right)\end{array}$ & $\begin{array}{c}\text { Removal } \\
\text { rates } \pm \mathrm{SE} \\
\left(\mu \mathrm{M} \mathrm{h} \mathrm{h}^{-1}\right)\end{array}$ \\
\hline 1 & $1,919 \pm 92$ & $0.21 \pm 0.04$ & $0.06 \pm 0.16$ \\
2 & $1,128 \pm 201$ & $0.20 \pm 0.20$ & $0.13 \pm 0.16$ \\
3 & $378 \pm 257$ & $-0.07 \pm 0.07$ & $0.002 \pm 0002$ \\
5 & $2,010 \pm 84$ & $0.22 \pm 0.22$ & $0.08 \pm 0.33$ \\
\hline
\end{tabular}

depth, depth-related patterns were not consistent among the different stations. In agreement with expectations based on $\mathrm{Chl}$ levels, relatively high potential uptake rates were observed at the mid-epilimnion and near-oxycline depths at the northern and central stations. However, rates were not distinguishable from zero at the near-oxycline depths for the southern stations or for the 5-m depth at Sta. 4 .

The Chl-specific uptake rates in surface waters were much higher at Stas. 2 and 3, located in more central regions of the lake, than at either Sta. 1 or the southern Stas. 4 and 5. The differences in Chl-specific ammonium uptake rates among stations may be partially explained by the different taxonomic composition of predominant algal species. For example, Sta. 2 was overwhelmingly dominated by chroococcoid cyanobacteria, whereas large chain-forming centric diatoms accounted for most of the phytoplankton community in Sta. 5 (G. Lavrentyeva pers. comm., State Res. Inst. Lake River Fish., St. Petersburg, Russia). These cyanobacteria have high biomass-specific uptake rates and are capable of sustaining these rates while cell quota is rapidly increasing (Stockner and Antia 1986).

Effects of sunlight on cycling rates in near surface waters-As mentioned above, the highest $\mathrm{N}$ cycling rates were observed in the treatments where near-surface water samples were incubated in polypropylene syringes. In these syringes, the sunlight was either diffused by the cloudy polypropylene and shaded with one layer of screen (light treatments) or eliminated by duct tape that had been wrapped around the syringes before incubations were begun (dark treatments). In addition, the syringes did not contain air-water surfaces, as did the other fixed-volume containers

Mean uptake rates were usually higher in the light than in the dark for water from the same stations, but differences were not significant at any of the stations where light and dark treatments were compared. The similarity of light and dark uptake rates supports the idea that Lake Maracaibo phytoplankton were relatively deprived of $\mathrm{N}$; N-deprived phytoplankton have greater dark uptake rates than do N-replete phytoplankton (Cochlan et al. 1991). Similarly, ammonium regeneration rates did not follow a consistent pattern between light and dark bottles. Mean rates were higher in the light than in the dark at Stas. 3 and 5, but the opposite was true at Sta. 1, and the SEs overlapped for light and dark bottles at all the stations that were compared. These results 
contrast with studies in the Gulf of Mexico Mississippi River plume. In that system, communities incubated in lighted polystyrene bottles, contained in a blue-tinted Plexiglas incubator that blocked ultraviolet rays and about $50 \%$ of incident light (Lohrenz et al. 1988), consistently showed higher rates for both ammonium uptake and regeneration than did similar dark bottles (Gardner et al. 1997).

The observation that ammonium uptake rates were consistently lower in quartz and polystyrene bottles than in light or dark polypropylenc syringes could suggest that photoinhibition reduced ammonium uptake when the samples were exposed to sunlight during the isotope addition experiments. Alternatively, the results may possibly suggest that uptake and regeneration rates were reduced by factors related to the headspace in the quartz and polystyrenc bottles. For example, it is possible that fragile microbial food web organisms may have been damaged at the surface-water interface. However, the fact that uptake as well as regeneration rates were affected strongly by the incubation vessel differences provides support for the differential light hypothesis. If the observed differences were due to light inhibition of ammonium uptake, these results suggest that, in nature, $\mathrm{N}$ uptake rates may be lower in surface waters, with high light exposure, than in water sufficiently deep to attenuate the light that otherwise would inhibit the uptake process. Thus, our surface-water measurements in the polypropylene syringes may have overestimated actual uptake rates by preventing light inhibition. Incubation in ultraviolet-shielding vessels may overestimate surface-water ammonium uptake by about 50\% (Behrenfeld et al. 1995). However, at the other extreme, incubating subsurface samples in quartz bottles at the water surface would overexpose the samples to ultraviolet and other light. Ideally, incubations should be done at actual depths in quartz containers to maintain actual light conditions, but this approach is often not feasible for logistical reasons.

Our data do not distinguish the exact organisms or processes responsible for the inhibition of ammonium uptake in Lake Maracaibo. The fact that rates were often comparable in the polystyrene culture bottles (with one screen) to those in the quartz bottles may imply that the photoinhibition, over that observed in the polypropylene syringes, was caused by light passing through the polystyrene as well as through the quartz container walls. This result may indicate that visible, as well as UV light, affects the inhibition process. One possible explanation could be light inhibition of nitrification (Lipschultz et al. 1985). The higher cycling rates observed in the polypropylene syringes than in the polystyrene culture bottles, with similar degrees of light penetration, may suggest that the quality of light passing through the different types of plastic walls may have caused different responses in the two types of containers. Differences in spectral quality were verified by examining the wavelengths of light absorbed by container walls of the two different types of plastic. The polypropylene syringe wall absorbed more light than the polystyrene bottle wall at all wavelengths, but the differences were substantial between 380 and $550 \mathrm{~nm}$ wavelengths, a part of the wavelength spectrum where green and bluegreen algae and diatoms all have peaks in light absorption (Kirk 1994). Although both types of plastic absorb ul- traviolet light quite strongly, the syringe also absorbed more light in the 300-380-nm range than did the culture bottle.

Previous work on the Delaware River indicated that ammonium uptake rate in surface waters clearly increased with light intensity over the intensity range of $0-800 \mu \mathrm{E} \mathrm{m}^{-2} \mathrm{~s}^{-1}$. On the other hand, ammonium oxidation rates decreased with increased light intensity between 0 and $250 \mu \mathrm{E} \mathrm{m}^{-2} \mathrm{~s}^{-1}$ (Lipschultz et al. 1985). Similarly, in the Strait of Georgia, British Columbia (Canada) surface-water uptake rates increased or plateaued as light intensities increased from 0 to $800 \mu \mathrm{E} \mathrm{m}^{-2} \mathrm{~s}^{-1}$ (Cochlan et al. 1991). Inhibition of algal photosynthesis by ultraviolet (UV) radiation has been well documented in laboratory studies (Hader 1996; Vincent and Roy 1993). Exposure to solar UVB (280-315 nm) radiation affects orientation and motility as well as photosynthesis and $\mathrm{N}$ uptake and other key physiological processes in phytoplankton (Behrenfield et al. 1995; Hader 1996). Nitrogenlimited diatoms are more sensitive to UVB radiation than $\mathrm{N}$ replete algae because turnover of critical protein synthesis associated with photosynthesis is inhibited (Lesser et al. 1994).

Photochemical regeneration of ammonium in surface waters-A previous study has provided evidence for photochemical release of biologically available $\mathrm{N}$, mostly as ammonium, from dissolved organic matter and isolated humic materials (Bushaw et al. 1996). Our preliminary studies with filtered lake water incubated in quartz tubes support this conclusion for photochemical degradation of DON at natural concentrations in Lake Maracaibo. Our mean photochemical ammonium regeneration rates of about $0.20 \mu \mathrm{M} \mathrm{h}^{-1}$ under bright sunlight fell within the range of ammonium production rates of $0.05-0.37 \mu \mathrm{M} \mathrm{h}^{-1}$ that Bushaw et al. (1996) observed for humic-rich dissolved organic matter from a variety of aquatic systems. Furthermore, our preliminary results imply that photochemical oxidation of DON could represent up to $\sim 30 \%$ of total near-surface ammonium regeneration under bright sunlight but would be negligible under cloudy conditions. They are consistent with the idea that this process could be a measurable producer of available ammonium in surface waters of Lake Maracaibo. The actual contribution of photochemical degradation to total ammonium regeneration in the lake would of course be much lower than $30 \%$ because respiration would continue at night or under cloudy conditions, whereas photochemical oxidation would not. In addition, the light energy driving the photochemical process would be attenuated more with water depth than would biological regeneration processes. For example, in Swedish lakes, photochemical degradation of organic carbon was comparable (overlapping values) to plankton community respiration in surface waters but was much smaller relative to community respiration $(<20 \%)$ on a depth-integrated basis (Graneli et al. 1996). However, our results here and in the Gulf of Mexico (Gardner et al. 1993) indicate that biological ammonium regeneration rates are also higher in surface waters than in subsurface waters. The complex relationships between autotrophic and heterotrophic nutrient cycling processes and photochemical interactions remain to be unraveled. 


\section{Conclusions}

Ammonium concentrations were low in Lake Maracaibo, but water column $\mathrm{N}$ cycling rates were exceptionally high, as evidenced by potential uptake and regeneration rates of ammonium that were comparable or higher than rates previously reported in the literature. The high ratios of recycled $\mathrm{N}$ to ambient concentrations of ammonium or nitrate provides evidence that biological recycling is an important source of $\mathrm{N}$ available to primary producers. The high cycling rates are undoubtedly driven by the hypereutrophic status, with associated elevated microbial food web biomass, and the high temperature and solar intensity of the lake. Internal recycling of $\mathrm{N}$ occurring in the oxygenated part of the water column may be particularly important to the high primary productivity in the lake. Nitrogen dynamics in surface waters may be affected by high light intensities at Lake Maracaibo. For example, $\mathrm{N}$ uptake was much lower in experimental waters that were held in quartz or clear polystyrene bottles than in shaded polypropylene syringes during incubations. Isotope dilution experiments on filtered surface water indicated that photochemical degradation of DON is measurable but would be quite small relative to biological regeneration rates integrated over the water column.

\section{References}

American Public Health Association (APHA). 1990. Standard methods for the examination of water and wastewater, 17 th ed. APHA.

Beaver, J. R., ANd T. L. Crisman. 1982. The trophic response of ciliated protozoa in freshwater lakes. Limnol. Oceanogr. 27: 246-253.

Behrenfeld, M. J., D. R. S. LeAN, AND H. LeE II. 1995. Ultraviolet-B radiation effects on inorganic nitrogen uptake by natural assemblages of oceanic plankton. J. Phycol. 31: 25-36.

BlackBuRn, H. T. 1979. Method for measuring rates of $\mathrm{NH}_{4}^{+}$turnover in anoxic marine sediments, using a ${ }^{15} \mathrm{~N}-\mathrm{NH}_{4}^{-}$dilution technique. Appl. Environ. Microbiol. 37: 760-765.

BusHAw, K. L., AND OTHERS. 1996. Photochemical release of biologically available nitrogen from aquatic dissolved organic matter. Nature 381: 404-407.

Caperon, J., D. Schell, J. Hirota, and E. Laws. 1979. Ammonium excretion rates in Kaneohe Bay, Hawaii, measured by a ${ }^{15} \mathrm{~N}$ isotope dilution technique. Mar. Biol. 54: 33-40.

Caron, D. A., and J. C. Goldman. 1990. Protozoan nutrient regeneration, p. 283-306. In G. M. Capriulo [ed.], Ecology of marine protozoa. Oxford Univ. Press.

Chróst, R. J., AND J. Overbeck. 1987. Kinetics of alkaline phsphatase activity and phosphorus availability for phytoplankton and bacterioplankton in Lake Plussee (north German eutrophic lake). Microb. Ecol. 13: 229-248.

Cochlan, W. P., N. M. Price, and P. J. Harrison. 1991. Effects of irradiance on nitrogen uptake by phytoplankton: comparison of frontal and stratified communities. Mar. Ecol. Prog. Ser. 69: 103-116.

COTNER, J. B., AND W. S. GARDNER. 1993. Heterotrophic bacterial mediation of ammonium and dissolved free amino acid fluxes in the Mississippi River plume. Mar. Ecol. Prog. Ser. 93: 7587.

FENCHEL, T. 1987. Ecology of protozoa. The biology of free living phagotrophic protists. Springer.

FINLAY, B. J., C. R. CURDS, S. S. BAMFORTh, AND J. M. BAFORT.
1987. Ciliated protozoa and other microorganisms from two African soda lakes Lake Nakuru and Lake Simbi, Kenya. Arch. Protistenkd. 133: 81-91.

Fisher, T. R., R. D. Doyle, And E. R. PeEle. 1988. Size-fractionated uptake and regeneration of ammonium and phosphate in a tropical lake. Verh. Int. Verein. Limnol. 23: 637-641.

Gardner, W. S., H. A. Bootsma, C. Evans, and P. A. St. John. 1995a. Improved chromatographic analysis of ${ }^{15} \mathrm{~N}:{ }^{14} \mathrm{~N}$ ratios in ammonium or nitrate for isotope addition experiments. Mar. Chem. 48: 271-282.

, J. F. Cavaletto, J. B. Cotner, and J. R. Johnson. 1997. Effects of natural light on nitrogen cycling rates in the Mississippi River plume. Limnol. Oceanogr. 42: 273-281.

- , J. B. Cotner, JR., AND L. R. Herche. 1993. Chromatographic measurement of nitrogen mineralization rates in marine coastal waters with ${ }^{15} \mathrm{~N}$. Mar. Ecol. Prog. Ser. 93: 65-73.

, AND OTHERS. 1994. Mineralization of organic material and bacterial dynamics in Mississippi River plume water. Estuaries 17: $816-828$.

- AND OTHERS. 1995b. Effects of the zebra mussel, Dreissena polymorpha, on community nitrogen dynamics in Saginaw Bay, Lake Huron. J. Great Lakes Res. 21: 529-544.

- AND P. A. ST. JOHN. 1991. High-performance liquid chromatographic method to measure ammonium ion and primary amines in seawater. Anal. Chem. 63: 537-540.

GessNer, F. 1956. Das plankton des Lago Maracaibo, p. 66-92. Ergebnisse der Deutchen Limnologischen Venezuela expedition 1952 , band 1 .

Graneli, W., M. Lindell, and L. Tranvik. 1996. Photo-oxidative production of dissolved inorganic carbon in lakes of different humic content. Limnol. Occcanogr. 41: 698-706.

HADER, D. P. 1996. Effects of enhanced solar UV-B radiation on phytoplankton. (suppl. 1) Sci. Mar. 60: 59-63.

HAGA, H., T. NAGATA, AND M. SAKAMOTO. 1995. Size fractionated $\mathrm{NH}_{4}^{+}$regeneration in the pelagic environments of two mesotrophic lakes. Limnol. Oceanogr. 40: 1091-1099.

HANSON, R. B., AND OTHERS. 1990. Nitrogen recycling in coastal waters of southeastern U.S. J. Mar. Res. 48: 641-660.

Hecky, R. E., AND H. J. KLING. 1981. The phytoplankton and protozooplankton of the euphotic zone of Lake Tanganyika: Species composition, biomass, chlorophyll content and spatio-temporal distribution. Limnol. Oceanogr. 26: 548-564.

KAlFF, J., AND S. WATSON. 1986. Phytoplankton and its dynamics in two tropical lakes: A tropical and temperate zone comparison. Hydrobiologia 138: 161-176.

KILHAM, P., AND S. S. KILHAM. 1990. Endless summer: Internal loading processes dominate nutrient cycling in tropical lakes. Freshwater Biol. 23: 379-389.

KIRK, J. T. O. 1994. Light and photosynthesis in aquatic ecosystems. Cambridge.

Lesser, M. P., J. J. Culjen, ANd P. J. Neale. 1994. Carbon uptake in a marine diatom during acute exposure to ultraviolet-B radiation: Relative importance of damage and repair. J. Phycol. 30: $183-192$.

LEWIS, W. M., JR. 1985. Protozoan abundances in the plankton of two tropical lakes. Arch. Hydrobiol. 104: 337-343. 84.

Lindei.l, M. I., H. W. Graneli, and J. I. Tranvik. 1996. Effects of sunlight on bacterial growth in lakes of different humic content. Aquat. Microb. Ecol. 11: 135-141.

LipsChultz, F., S. C. WOFSY, AND L. E. Fox. 1985. The effects of light and nutrients on rates of ammonium transformation in a eutrophic river. Mar. Chem. 16: 329-341.

— - - 1986. Nitrogen metabolism of the 
eutrophic Delaware River ecosystem. Limnol. Oceanogr. 31: 701-716.

LOHRENZ, S. E., AND OTHERS. 1988. Interrelationships among primary production, chlorophyll, and environmental conditions in frontal regions of the western Mediterranean Sea. Deep-Sea Res. 35: 793-810.

Miller, C. A., D. L. Penry, And P. M. Glibert. 1995. The impact of trophic interactions on rates of nitrogen regeneration and grazing in Chesapeake Bay. Limnol. Oceanogr. 40: 1005-1011.

MorRISSEY, K. M., AND T. R. FISHER. 1988. Regeneration and uptake of ammonium by plankton in an Amazon floodplain lake. J. Plankton Res. 10: 31-48.

NAKANO, S. 1994. Carbon : nitrogen : phosphorus ratios and nutrient regeneration of a heterotrophic flagellate fed on bacteria with different elemental ratios. Arch. Hydrobiol. 129: 257-271.

NORL_AND, S. 1993. The relationship between biomass and volume of bacteria, p. 303-307. In P. F. Kemp, B. F. Sherr, E. B. Sherr, and J. J. Cole [eds.], Handbook of methods in aquatic microbial ecology. Lewis.

PAKUlski, J. D., AND OTHers. 1995. Community metabolism and nutrient cycling in the Mississippi river plume: Evidence for intense nitrification at intermediate salinities. Mar. Biol. Ecol. Prog. Ser. 117: 207-218.

PARri-PARDI, G. 1983. Cone-shaped hypolimnion and local reactor as outstanding features in eutrophication of Lake Maracaibo. J. Great Lakes Res. 9: 439-451.

1986. La conservacion del Lago de Maracaibo diagnóstico ecologico y plan maestro (Lake view of Lake Marcaibo, watershed conservation of Lake Maracaibo, ecological diagnosis and master plan). Lagoven Filial De Petroleos de Venezuela, S.A.

Porter, K. G., AND Y. G. Feig. 1980. The use of DAPI for identifying and counting aquatic microflora. Limnol. Oceanogr. 25: 943-948.

Putt, M., and D. K. Stoecher. 1989. An experimentally determined carbon: volume ratio for marine oligotrichous ciliates from estuarine and coastal waters. Limnol. Oceanogr. 34: 177183.

RfDField, A. C. 1958. Preludes to the entrapment of organic matter in the sediments of Lake Maracaibo, p. 968-981. In Habitat of oil. Am. Assoc. Petrol. Geologists.
- AND L. A. EARLSTON DoE. 1964. Lake Maracaibo. Verh. Int. Verein. Limnol. 15: 100-111.

SAnders, R. W., D. A. Caron, AND U. G. Berninger. 1992. Relationship between bacteria and heterotrophic nanoplankton in marine and fresh waters: An inter-ecosystem comparison.. Mar. Ecol. Prog. Ser. 86: 1-14.

Scavia, D., and G. L. Fahnenstiel. 1987. Dynamics of Lake Michigan phytoplankton: Mechanisms controlling epilimnetic communities. J. Great Lakes Res. 13: 103-120.

SELMER, J. S. 1988. Ammonium regeneration in eutrophicated coastal waters of Sweden. Mar. Ecol. Prog. Ser. 44: 265-273.

, C. Ferrier-Pages, C. Cellario, and F. RassoulzadeGAN. 1993. New and regenerated production in relation to the microbial loop in the NW Mediterranean Sea. Mar. Ecol. Prog. Ser. 100: 71-83.

Strickland, J. D. H., AND T. R. PARsons. 1972. A practical handbook for seawater analysis, 2nd ed. Bull. Fish. Res. Board Can. 167.

STOCKNER, J. G., AND N. J. ANTIA. 1986. Algal picoplankton from marine and freshwater ecosystems: A multidisciplinary perspective. Can. J. Fish. Aquat. Sci. 43: 2472-2503.

SuTTON, E. A. 1974. Study of effects of oil discharges an domestic and industrial wastewaters on the fisheries of Lake Maracaibo, Venczuela. In W. L. Templeton [ed.], Ecological characterization and domestic and industrial wastes. Battelle Pacific Northwest Laboratories.

Suzuki, M. T., E. B. ShERr, AND B. F. Sherr. 1993. DAPI direct counting underestimates bacterial abundances and average cell size compared to AO direct counting. Limnol. Oceanogr. 38: $1566-1569$.

1996. Estimation of ammonium regeneration efficiencies associated with bacterivory in pelagic food webs via a ${ }^{15} \mathrm{~N}$ tracer method. J. Plankton Res. 18: 411428.

U.S. EnVironmental. Protection Agency (USEPA). 1974. Methods for chemical analysis of water and wastes. EPA 625-/674-003a. Cincinnati.

VinCENT, W. F., AND S. Roy. 1993. Solar ultraviolet-B radiation and aquatic primary production: Damage, protection, and recovery. Environ. Rev. 1: 1-12.

Received: 18 April 1997

Accepted: 6 January 1998 